\title{
Urologie is meer dan oncologie alleen
}

\author{
Henk G. van der Poel ${ }^{1}$
}

We zouden het bijna vergeten, maar urologie is meer dan oncologie alleen. Tijdens de voorjaarsvergadering in Leiden bleek wederom de grote aandacht binnen ons vakgebied voor maligniteiten. In veel gevallen, zoals bij het gelokaliseerd prostaat- en niercarcinoom, zijn er geen klachten en is de behandeling vaak erger dan de kwaal, zeker op korte termijn. Dit is niet het geval bij de behandeling van goedaardige afwijkingen. Coen Holzhauer laat in zijn onderzoek zien dat een laserbehandeling voor urethrastricturen niet beter is dan de behandeling met het Sachse-mes. Misschien nog wel belangrijker is de bevinding dat stricturen die zijn behandeld met een van de technieken in meer dan $90 \%$ van de gevallen recidiveren. Een belangrijk argument dus om in deze groep in een vroegtijdig stadium een urethraplastiek te overwegen. Dit laatste is misschien iets wat we allemaal wel weten, maar waar we minder ervaring mee hebben dan zou hoeven. Ook weer zo'n onderdeel van ons vak dat best een beetje meer aandacht zou mogen krijgen. Vandaar een aantal voorbeelden van niet-oncologisch onderzoek in deze uitgave.

dr. Henk G. van der Poel hoofdredacteur

dr. Henk G. van der Poel

h.vd.poel@nki.nl

1 Tijdschrift voor Urologie, Bohn Stafleu van Loghum, Houten, Nederland 